\title{
Missed breast cancer in two patients with prepectoral silicone gel breast implants following implant displacement mammography
}

\author{
Walter Peters PhD MD FRCSC, Victor Fornasier MD FRCPC \\ Division of Plastic Surgery and Department of Pathology, Wellesley Central Hospital and the University \\ of Toronto, Toronto, Ontario
}

\begin{abstract}
W Peters, V Fornasier. Missed breast cancer in two patients with prepectoral silicone gel breast implants following implant displacement mammography. Can J Plast Surg 1997;5(2):127-129. Two patients with prepectoral silicone gel breast implants and class IV capsular contractures presented at explantation with incidental breast carcinomas, which had been missed following implant displacement mammography. In both patients, the radiologists had commented that imaging was difficult because of the presence of the implants and their associated capsular contractures. Both patients had metastases - one had involvement of multiple axillary lymph nodes and the other had widespread metastases to the liver and to multiple skeletal sites. The cases reinforce the findings that breast implants can mask the early detection of breast carcinoma.
\end{abstract}

Key Words: Breast carcinoma, Displacement mammography, Silicone gel breast implants

Cancer du sein non diagnostiqué chez deux patientes porteuses de prothèses mammaires prépectorales au gel de silicone après mammographie avec déplacement de l'implant (technique d'Eklund)

RÉSUMÉ : Deux patientes porteuses de prothèses mammaires prépectorales au gel de silicone et de contractures capsulaires de classe IV présentaient des cancers du sein au moment de l'explantation, cancers passés inaperçus après une mammographie avec déplacement de l'implant. Chez les deux patientes, les radiologistes avaient déclaré l'imagerie difficile à interpréter à cause de la présence des implants et des contractures capsulaires associées. Les deux patientes avaient des métastases, l'une avait une atteinte à de nombreux ganglions lymphatiques axillaires et chez l'autre, les métastases s'étaient répandues au foie et au squelette. Ces deux cas témoignent encore du fait que les prothèses mammaires peuvent nuire au dépistage précoce du cancer du sein.

$\mathrm{M}$ ammography is the primary method used for the early detection of breast cancer (1). In patients without breast implants, mammography usually involves two views in which the breast is compressed: a mediolateral oblique (MLO) view, where the breast is viewed from side to side, and a craniocaudal (CC) view, where the breast is viewed from top to bottom.

The presence of silicone breast implants has been shown to interfere with complete imaging of the breast (2-9). Hayes and associates (4) showed that when standard compression views were used, a breast implant obscured $22 \%$ to $83 \%$ of visualizable breast tissue. To improve imaging in breast implant patients, Eklund et al (8) developed the implant dis-

Correspondence and reprints: Dr Walter Peters, Wellesley Central Hosptial, Suite 418, 160 Wellesley Street East, Toronto, Ontario M4Y $1 J 3$. Telephone 416-926-7790, fax 416-926-4997, e-mail walter.peters@utoronto.ca placement technique, in which the breast tissue is drawn anteriorly away from the implant and is compressed between the x-ray film holder and the paddle. When this technique was used in patients with breast implants and the results were compared with pre-augmentation films, the visualized area was still decreased, but only by $25 \%(5,6)$. Compression and displacement methods complement each other. Posterior breast tissue is visualized best with compression, and anterior tissue is seen best with displacement (7). Mammography centres currently recommend a four-view mammogram in patients with breast implants - the two standard compression views (MLO and CC) and the same views repeated using the implant displacement technique (10).

The present report describes two patients who presented during the past year with a breast carcinoma that was missed following compression and displacement views and was discovered incidentally at the time of explantation of their implants. 


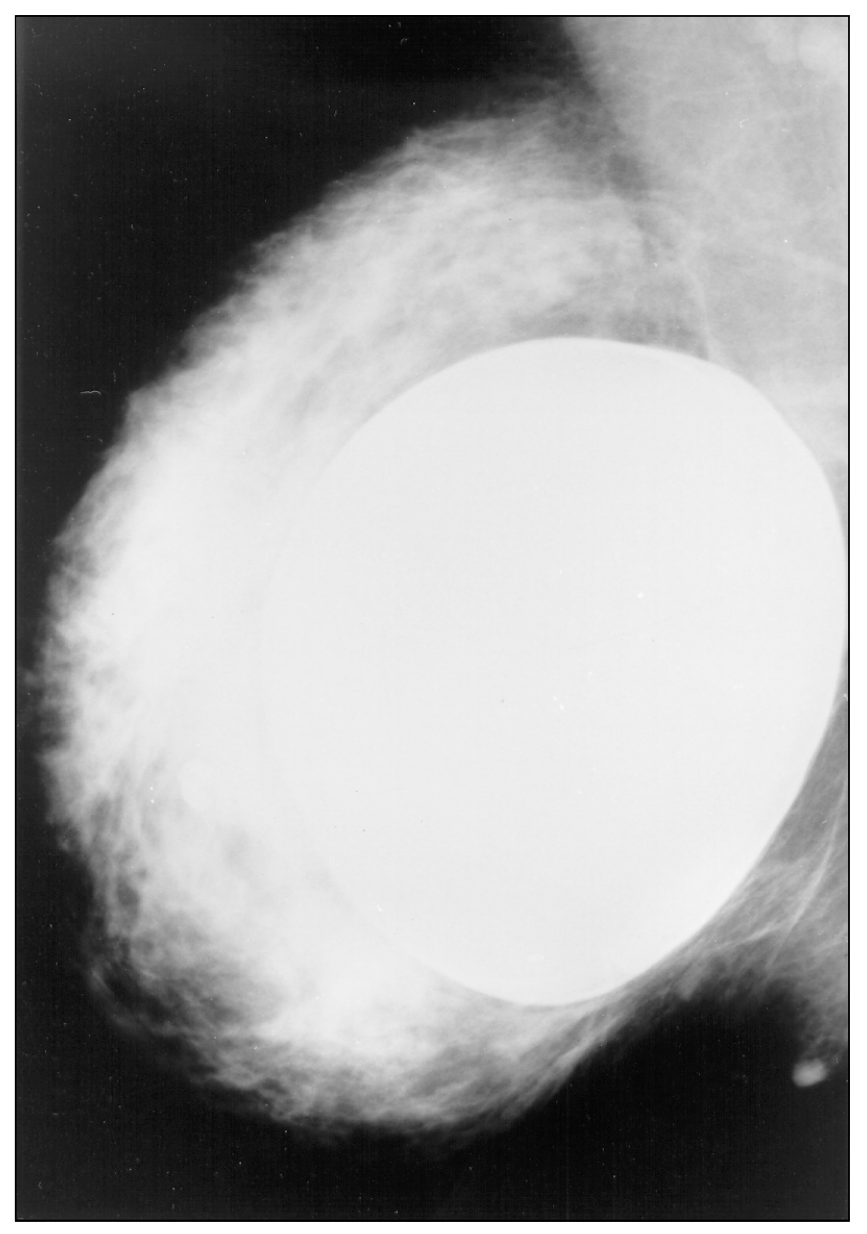

Figure 1) Mediolateral oblique mammogram of the right breast of case 1 showed no suspicious changes and was unchanged from a mammogram done one year previously

\section{Case 1}

\section{CASE PRESENTATIONS}

A 53-year-old woman presented with pain, redness and swelling in her right breast three weeks after her annual mammographic examination. She had received prepectoral silicone gel breast implants 23 years previously. She had a class IV contracture on the right side and a class II contracture on the left side. Her four-view mammogram showed no suspicious abnormalities and was unchanged from the examination done one year previously (Figure 1). The radiologist had commented that "the presence of implants impairs the ability to visualize breast tissue". There were no palpable lymph nodes. Physical examination was otherwise unremarkable.

Because her symptoms developed immediately following her mammographic evaluation, it was initially thought that they were related to the mammogram. However, when the patient was assessed one month later, the redness and swelling had increased significantly. A breast biopsy confirmed the diagnosis of inflammatory carcinoma. Subsequent investigations showed widespread metastases to liver and multiple skeletal sites. The patient refused further medical treatment.

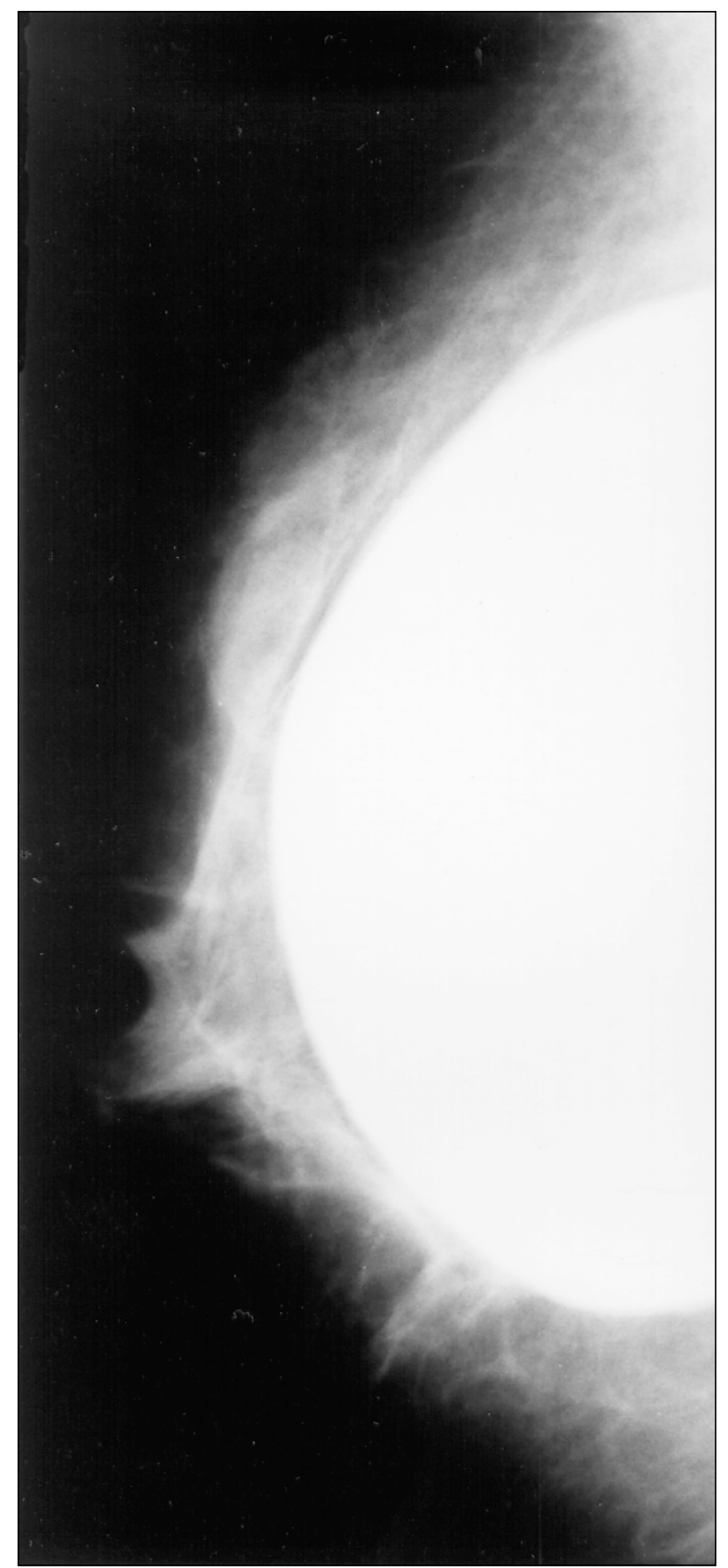

Figure 2) Mediolateral oblique mammogram of the left breast of case 2 showed no suspicious changes and was unchanged from a mammogram done one year previously

\section{Case 2}

A 56-year-old woman presented with class IV capsular contractures and requested explantation of her prepectoral silicone gel implants, which had been inserted 19 years previously for treatment of congenital aplasia. There were no breast masses and there was no palpable lymphadenopathy. She had undergone annual four-view mammograms for the past four years. Her current mammogram (Figure 2), com- 
pleted four months before explantation, was reported as normal and was unchanged from previous mammograms. The radiologist had noted that "mammography was difficult because of breast implants".

At explantation, a $1.3 \mathrm{~cm}$ firm round mass was found directly anterior to the capsule in the upper pole of the left breast. A biopsy confirmed the diagnosis of carcinoma with involvement of axillary lymph nodes. The patient subsequently underwent a modified radical mastectomy and a course of chemotherapy.

\section{DISCUSSION}

Mammography is the primary method used for the early detection of breast cancer. The most favourable breast carcinomas, those with $90 \%$ to $95 \%$ five-year survival rates, are occult (nonpalpable) lesions found in asymptomatic women following mammography (9). Several reviews of case series of women who developed breast cancer after breast implants have been done (11). However, all of these studies were done before the introduction of the displacement technique. Missed breast carcinoma after implant displacement mammography is considered to be relatively uncommon (7).

There is disagreement regarding whether the presence of implants delays the diagnosis of breast carcinoma in a clinically important manner (12). Silverstein and co-workers $(5,6)$ described 20 women with breast implants who developed breast carcinoma. The disease in these women was more advanced (more invasive and with more positive nodes) than that of comparable patients without implants. Other investigators have found no differences in the staging of breast carcinoma in augmented versus nonaugmented patients (12). Birdsell and associates (12) studied the stage at diagnosis and the survival experience of 41 women who developed breast cancer after augmentation, and compared those values with those of all other 13,246 women diagnosed with breast cancer in Alberta from 1973 to 1990. This study concluded that women with breast implants in whom breast cancer developed are not diagnosed at a later stage and did not experience decreased survival compared with breast cancer patients without implants. In the present study, both patients had advanced disease; one had involvement of multiple axillary lymph nodes and the other had widespread metastases to liver and to multiple skeletal sites.

Many studies have demonstrated that the presence of breast implants interferes with correct imaging of breasts (2-9). Even with proper four-view mammograms, the visualized area of augmented breasts appears to be decreased by about $25 \%$ compared with the view in nonaugmented breasts (4-6). The more severe the contracture, the poorer the quality of mammography. Better films are obtained when the implant is submuscular rather than subglandular $(5,6)$. The best images are obtained from women with submuscular implants and no substantial capsular contracture (11).

The two patients in the present report demonstrated class IV capsular contractures in their breasts that developed carcinoma. In both patients, the radiologists had commented on imaging difficulties because of these contractures. In the first case, the patient's symptoms occurred immediately after mammographic assessment, suggesting that they were due to mammographic manipulation. The fact that they failed to settle prompted further investigations. These two cases emphasize that severe capsular contractures in augmented breasts may well mask the early detection of a breast carcinoma.

ACKNOWLEDGEMENTS: This research was funded by a Medical Research Council of Canada University Industry Grant and by an Outcome Grant from the Canadian Society of Plastic Surgeons.

\section{REFERENCES}

1. Bassett LW, Hendrick RE, Bassford TL, et al. Quality Determinants of Mammography. Clinical Practice Guideline No 13. AHCPR Publication No 95-0632. Rockville: US Department of Health and Human Services, Public Health Service, Agency for Health Care Policy and Research, 1994.

2. Shestak KC, Ganott MA, Harris KM, et al. Breast masses in the augmentation mammoplasty patient: the role of ultrasound. Plast Reconstr Surg 1993;92:209-16.

3. Eklund GW, Cardenosa G. The art of mammographic positioning. Radiol Clin North Am 1992;30:21-53.

4. Hayes H Jr, Vandergrift J, Diner WC. Mammography and breast implants. Plast Reconstr Surg 1988;82:1-6.

5. Silverstein MJ, Handel N, Gamagami P, et al. Breast cancer in women after augmentation mammoplasty. Arch Surg 1988;123:681-5.

6. Silverstein MJ, Handel N, Gamagami P, et al. Breast cancer diagnosis and prognosis in women following augmentation with silicone gel-filled prostheses. Eur J Cancer 1992;28:635-40.

7. Silverstein MJ, Gamagami P, Hadel N. Missed breast cancer in an augmented woman using implant displacement mammography. Ann Plast Surg 1990;25:210-3.

8. Eklund GW, Busby RC, Miller SH, et al. Improved imaging of the augmented breast. Am J Roentgenol 1988;151:469-73.

9. Silverstein MJ, Gamagami P, Colburn WJ. Nonpalpable breast lesions: Diagnosis with slightly overpenetrated screen-film mammography and hook wire-directed breast biopsy in 1014 cases. Radiology 1989:171:633-8.

10. Peters WJ, Smith S, Grosman H, Fornasier V. Role of mammography to assess complications of silicone gel breast implants. Can J Plast Surg 1995;3:150-6.

11. Silverman BG, Brown SL, Bright RA, et al. Reported complications of silicone gel breast implants: An epidemiologic review. Ann Intern Med 1996;124:744-56.

12. Birdsell DC, Jenkins $H$, Berkel H. Breast cancer diagnosis and survival in women with and without breast implants. Plast Reconstr Surg 1993;92:795-800. 